\title{
Cechy wpływajace na odbiór i opinię o reklamie
}

Reklama, sposób jej odbioru czy szeroko pojęta atrakcyjność dla odbiorcy już od dawna są przedmiotem badań. Zazwyczaj jednak koncentrują się one na istniejących produktach i markach, nie są ogólnie dostępne i nie ujmują zjawiska reklamy w szerszym kontekście.

Zauważono, że reklama jest konstruktem, który ma dwie wyraźne płaszczyzny odbioru wśród publiczności. Uznaje się ją spontanicznie za dobrą lub złą, a za taką ogólną oceną rzadko kiedy idą dalsze, bardziej szczegółowe osądy i interpretacje. Postanowiono zatem sprawdzić, jakie cechy są komunikowane przez respondentów w kontekście obrazu dobrej i złej reklamy.

\section{Funkcje reklamy}

Reklama jako zjawisko będące obiektem zainteresowania wielu dziedzin nauki charakteryzuje się brakiem uniwersalnej operacjonalizacji pojęcia. W zależności od poszczególnych obszarów (socjologia, psychologia, ekonomia, językoznawstwo) definicje będą się mniej lub bardziej różniły. Podobnie jest w wypadku funkcji reklamy. Jedną z typologii prezentuje Piotr H. Lewiński, który wyróżnia trzy główne cele reklamy: perlokucyjny, perswazyjny i informacyjny.

Cel perlokucyjny jest ostatecznym celem komunikatu i zostaje osiągnięty w momencie, kiedy odbiorca zaczyna działać w pożądany sposób. Ten cel jest niejako zewnętrzny, jest poza zasięgiem struktury komunikatu i może zależeć od wielu czynników [...]. 
Celem perswazyjnym [...] jest zachęcenie odbiorcy do działania, wzbudzenie i utrzymanie w nim przekonania, że wybór, jakiego dokonuje, da mu pełną satysfakcję [...].

Celem informacyjnym [...] jest informowanie o towarze bądź usłudze ${ }^{1}$.

Jest to dość szeroka typologia, patrząc chociażby z perspektywy J. Douglasa Johnsona, który wyodrębnia aż 24 funkcje reklamy ${ }^{2}$. Wyznacza on:

-10 funkcji prezentacyjnych,

-3 funkcje kontastujące,

-6 funkcji perswazyjnych,

-5 funkcji kwalifikacyjnych.

Z kolei badacze zajmujący się reklamą z perspektywy funkcjonalno-systemowej koncentrują się na aspekcie tworzenia wizerunku i budowania świata przeżyć. Do najważniejszych według Niklasa Luhmanna funkcji reklamy należy to, „by ludzi pozbawionych smaku wyposażyć w smak"3. Smak jest wartością, która służy pożądaniu. Wyposażenie w smak ma więc za zadanie wywołać u odbiorcy pożądanie i relewantną reakcję w stosunku do danego przedmiotu.

Michael Fleischer, odnosząc się do zjawiska reklamy, pisze, że: „[r]eklama pokazuje nam, jak świat mógłby wyglądać, kiedy będzie się posiadało dane coś” lub „pokazuje nam, jak coś (x) będzie mogło wyglądać, kiedy w rezultacie kupna będzie się posiadało coś innego (y)"4. Takie definiowanie reklamy jest związane z kluczową rolą, jaką $\mathrm{w}$ całym procesie odgrywa transportowanie świata przeżyć produktu i/lub organizacji w sferę komunikacji. Według Fleischera jest to najważniejsza funkcja reklamy, ponieważ sama w sobie nie ma ona informować o przedmiocie, lecz zaświadczać o jego obecności na rynku właśnie poprzez transportowanie konkretnego świata przeżyć.

Funkcja sprzedażowa reklamy jest najbardziej powszechna w ujęciu rynkowym. Amerykańskie Stowarzyszenie Marketingowców w 1948 r. zdefiniowało reklamę jako wszelką płatną formę nieosobowego przedstawiania i popierania towarów, usług lub idei przez określonego nadawcę. Jest to sformułowanie dość ogólne, dlatego też warto przytoczyć inne spojrzenia na to zagadnienie.

Jacek Kall w tym aspekcie dodaje, że o „reklamie mówimy wówczas, gdy w sposób bezosobowy (bez udziału sprzedawcy) i za pieniądze prezentuje się produkt lub usługe" 5 .

Philip Kotler, jeden z najbardziej znanych autorów podręczników i teorii z zakresu marketingu, zwraca $\mathrm{z}$ kolei uwagę na znaczenie reklamy dla organizacji. Pisze on:

${ }_{1}^{1}$ P.H. Lewiński, Retoryka reklamy, Wrocław 2008, s. 31.

2 Zob. ibidem, s. 31-35.

${ }^{3}$ N. Luhmann, Realność mediów masowych, przeł. J. Barbacka, Wrocław 2009, s. 56.

${ }^{4}$ M. Fleischer, Reklama. Struktura i funkcje w wymiarze komunikacyjnym, Łódź 2011, s. 24.

5 J. Kall, Reklama, Warszawa 2010, s. 17. 
Organizacje wykorzystują reklamę, aby uzyskać dwa rodzaje reakcji (każda reklama ma bowiem na celu wywołanie reakcji). Pierwszą z nich jest reakcja natury perceptualnej, np. klient wyrabia sobie określony pogląd na temat danego produktu czy marki lub reklama wpływa na zmianę jego odczuć w stosunku do niej. Możliwa jest także reakcja natury behawioralnej, to znaczy taka, kiedy konsument dokonuje zakupu produktu lub kupuje go w większej ilości ${ }^{6}$.

\section{Konstrukt dobrej i złej reklamy wśród odbiorców}

W celu sprawdzenia, jak konstruowany jest obraz dobrej i złej reklamy, przeprowadzono badanie. Zostało ono zrealizowane metodą ankietową na grupie 100 osób w okresie styczeń-luty 2015 r. Odbywało się w Instytucie Dziennikarstwa i Komunikacji Społecznej oraz Instytucie Informatyki Uniwersytetu Wrocławskiego. Pytania, które poddano analizie, to:

- Jaka jest Pana/Pani zdaniem dobra reklama?

- Jaka jest Pana/Pani zdaniem zła reklama?

- Po czym poznaje się Pana/Pani zdaniem dobrą reklamę?

- Po czym poznaje się Pana/Pani zdaniem złą reklamę?

- Jakie są osoby, które robią dobre reklamy?

- Jakie są osoby, które robią złe reklamy?

Jako metodologią relewantną do obszaru i charakteru badania posłużono się badaniem komunikacji opierającym się na ocenie wizerunku. Pojęcie to może być rozpatrywane na wiele sposobów. Michael Fleischer, który odnosi się do problematyki wizerunku od strony założeń konstruktywizmu, pisze, że:

Wizerunek zatem jest tym, co funkcjonuje na temat organizacji zewnętrznie na rynku, jest tym, co my o danej organizacji społecznie mniemamy ${ }^{7}$.

lub

Wizerunek jest tym, co ludzie o organizacji na zewnątrz sądzą (kimkolwiek owi „ludzie” by byli) ${ }^{8}$.

Badania komunikacji mają na celu sprawdzenie bądź zweryfikowanie przedmiotu badań, niezależnie od tego, czy jest to instytucja, osoba, symbol kolektywny, pojęcie czy konstrukt. Można więc powiedzieć, że są one uniwersalne i mogą mieć naprawdę szerokie zastosowanie. Zdaniem Michała Grecha:

Badania wizerunku badają na pewno znane sposoby komunikacji o przedmiocie badań. O tym, co jeszcze badają, trudno jest jednoznacznie orzekać na gruncie badań komunikacji, choć bywa to bardzo

${ }^{6}$ P. Kotler et al., Marketing. Podręcznik europejski, przeł. L. Adamus, W. Kisiel, M. Woźniczka, Warszawa 2002, s. 863.

${ }^{7}$ M. Fleischer, Communication design, czyli projektowanie komunikacji, Łódź 2010, s. 215.

${ }^{8}$ Ibidem. 
pociągające - szczególnie stwierdzanie, że wypowiadający nie tylko wypowiada, ale podziela wszystkie wypowiadane opinie ${ }^{9}$.

Uwzględniając opisaną specyfikę badań komunikacji, można stwierdzić, że badanie na temat konstruktów dobrej i złej reklamy rozpatruje kwestię wizerunku. Nie jest to jednak wizerunek instytucji czy osoby, tylko konstrukcji językowej. Oczywiście można analizować samo zjawisko reklamy, lecz w tym wypadku bardziej interesujące wydaje się uwzględnienie w kontekście reklamy określeń „dobra/zła”, które do niej się odnosiły. Zauważono bowiem (w ramach osobistych doświadczeń), że ludzie mają skłonność do szybkiego klasyfikowania reklam właśnie w prostych kategoriach „dobra/zła” (czy też podobnych, jak „fajna/słaba”). Jeżeli jednak zadać spontaniczne pytanie, dlaczego ktoś uważa daną reklamę za dobrą czy złą, pojawiają się problemy z dokładniejszym opisem.

\section{Cechy dobrej i złej reklamy}

Pytanie „Jaka jest Pana/Pani zdaniem dobra/zła reklama?” miało na celu wywołanie spontanicznych konotacji respondentów z tymi terminami. Dzięki odpowiedziom powstaje coś w rodzaju image’u dobrej i złej reklamy oraz dominujących cech, za pomocą których jest ona kategoryzowana jako dobra/zła. Operowanie tylko tymi dwoma kategoriami jest zapewne o wiele łatwiejsze, ponieważ wymaga znacznie mniej uwagi i zaangażowania. Każdą reklamę da się bowiem ocenić jako dobrą lub złą, lecz gdy przychodzi do wyjaśnienia swojej opinii, okazuje się to już bardziej złożone i pokazuje rozbieżność opinii na temat tego, dlaczego dana reklama klasyfikowana jest właśnie w ten sposób.

Tabela 1. Jaka jest Pana/Pani zdaniem dobra reklama? Wyniki ogólne

\begin{tabular}{|c|c|c|c|}
\hline \multirow{2}{*}{ Kategoria } & \multirow{2}{*}{ Najczęstsze odpowiedzi } & \multicolumn{2}{|c|}{ Ogółem } \\
\hline & & Liczba & $\%$ \\
\hline ciekawa/interesująca/chwytliwa & $\begin{array}{l}\text { ciekawa }-14 \text {; interesująca }-6 \text {; przyciąga } \\
\text { uwagę }-5 \text {; chwytliwa }-5 \text {; przyciąga wzrok } \\
-4\end{array}$ & 49 & 18,9 \\
\hline $\begin{array}{l}\text { kreatywna/inteligentna/ } \\
\text { oryginalna }\end{array}$ & $\begin{array}{l}\text { pomysłowa }-7 \text {; inteligentna }-6 \text {; kreatywna } \\
-6 \text {; oryginalna }-6\end{array}$ & 34 & 13,2 \\
\hline łatwa/prosta & krótka -9 ; prosta -7 ; przejrzysta -5 & 32 & 12,5 \\
\hline
\end{tabular}

${ }^{9}$ M. Grech, Badanie wizerunku - metody ankietowe. Metodologia badań, [w:] Badanie wizerunku: ludzie, marki, branże, red. M. Grech, Wrocław-Łódź 2012, s. 13. 


\begin{tabular}{|c|c|c|c|}
\hline \multirow{2}{*}{ Kategoria } & \multirow{2}{*}{ Najczęstsze odpowiedzi } & \multicolumn{2}{|c|}{ Ogółem } \\
\hline & & Liczba & $\%$ \\
\hline nie denerwuje/nie przeszkadza & $\begin{array}{l}\text { nienachalna }-5 \text {; nienatarczywa }-3 \text {; } \\
\text { niedrażniąca }-2\end{array}$ & 25 & 9,7 \\
\hline zapada w pamięć & zapada w pamięć -10 ; zapamiętywana -6 & 23 & 8,9 \\
\hline emocjonalna & $\begin{array}{l}\text { kontrowersyjna }-2 \text {; szokująca }-2 \text {; } \\
\text { skłania do refleksji }-2\end{array}$ & 14 & 5,4 \\
\hline trafia do odbiorcy/dopasowana & dopasowana -3 ; trafia do odbiorcy -3 & 10 & 3,9 \\
\hline pokazuje produkt & pokazuje produkt -2 & 7 & 2,7 \\
\hline rzeczowa/merytoryczna & spójna -3 ; rzeczowa -2 & 8 & 3,1 \\
\hline przyjemna & przyjemna -2 & 2 & 0,8 \\
\hline skuteczna & skuteczna -3 & 3 & 1,2 \\
\hline profesjonalna & profesjonalna -2 & 2 & 0,8 \\
\hline obiektywna/prawdziwa & pojedyncze odpowiedzi & 2 & 0,8 \\
\hline inne & pojedyncze odpowiedzi & 21 & 8,2 \\
\hline & Razem & 257 & 100,0 \\
\hline
\end{tabular}

Źródło: opracowanie własne.

W odpowiedziach można zauważyć dużą różnorodność charakteryzowania dobrej reklamy. Zarówno w kategoriach, jak i w pojedynczych odpowiedziach nie widać takiej, która znacząco dominowałaby nad pozostałymi. Oznacza to, że określenie „dobra reklama" nie ma semantycznie jednolitego przełożenia na poszczególne cechy.

Najczęściej wymienianą kategorią dobrej reklamy jest „ciekawa/interesująca/ chwytliwa”. Określenia, które można do niej zakwalifikować, wskazało 18,9\% respondentów. Wśród pojedynczych odpowiedzi w tej kategorii wyraźnie najczęstszą było stwierdzenie, że dobra reklama jest ciekawa. Wskazuje to, że głównym walorem reklamy powinno być wzbudzanie u odbiorców zainteresowania, tak aby nie była ona neutralna czy obojętna. Gdy zostanie zauważona (a najlepiej równocześnie zapamiętana), oznacza to, że może zostać uznana za dobrą.

Na ważność zagospodarowania uwagi odbiorców przez reklamę wskazuje także inna licznie wymieniana kategoria, czyli „zapadająca w pamięć”. Uzyskała ona 8,9\%. Ona również w dużej mierze odnosi się do tego, że bez wzbudzania zainteresowania czy przyciągania uwagi reklama nie może być dobra.

Można by się nawet zastanowić, czy te kategorie nie są tak podobne semantycznie, że należałoby je połączyć w jedną, większą. Wówczas otrzymalibyśmy taką, która liczyłaby prawie $28 \%$ wskazań i byłaby zdecydowanie najliczniejszą z kategorii w tym 
pytaniu, ponad dwukrotnie przewyższając następną. W wypadku tego badania zrezygnowano jednak z takiego połączenia, ponieważ stwierdzono, że ciekawość w odniesieniu do reklamy niekoniecznie musi być równorzędna z pozostawaniem w pamięci. $\mathrm{Z}$ jednej strony ciekawość bliższa jest sytuacji, w której widzimy reklamę i w danym momencie przyciąga ona naszą uwagę i wzbudza zainteresowanie. Natomiast możliwe jest, że wcale nie pozostanie ona w naszej pamięci i dopiero, kiedy zobaczymy ją po raz kolejny, wrócą pozytywne skojarzenia. Z drugiej strony, zapadać w pamięć może reklama, która nie jest dla odbiorcy ciekawa, ale np. zawiera jakiś charakterystyczny element, który mimo woli sprawia, że zostaje ona zapamiętana.

Na drugim miejscu wśród najliczniejszych kategorii w odniesieniu do dobrej reklamy jest „kreatywna/inteligentna/oryginalna”. Kreatywność wydaje się kluczowym sformułowaniem odnoszącym się do tematyki reklamowej. Nie bez powodu agencje zajmujące się szeroko pojętą tematyką reklamową nazywane są agencjami kreatywny$\mathrm{mi}$ - jeden z podstawowych departamentów każdej profesjonalnej agencji to kreacja, na jej czele stoi dyrektor kreatywny, a pracownicy nazywani są potocznie „kreatywnymi”. Nie dziwi zatem fakt, że dobra reklama jest $\mathrm{w}$ dużej mierze utożsamiana właśnie $\mathrm{z}$ kreatywnością czy - w pozostałych przypadkach - z pomysłowością lub oryginalnością. Jeśli sami twórcy reklamowi uważają siebie i chcą być uważani za kreatywnych, to odbiorcy oczekują od nich, że produkty przez nich wytwarzane (reklamy) również będą kreatywne i nowatorskie.

Dobra reklama jest także „krótka, łatwa i prosta”. Takich odpowiedzi udzieliło $12,5 \%$ respondentów. Wskazuje to, że - po pierwsze - reklama ma nie przeszkadzać przy konsumowaniu właściwych treści, jak np. program telewizyjny, a po drugie - że jeśli już jest, to ma być zrozumiała dla odbiorcy, tak aby nie musiał się on nad nią zastanawiać po zakończeniu emisji. Większość ludzi deklaruje, że nie lubi reklam. Dlatego wydaje się, że te cechy mogą niwelować odczucia niechęci wobec reklamy, a nawet spowodować, że będzie ona oceniana jako dobra. Do tej kategorii pasuje również inna odpowiedź, którą wskazało 9,7\% ankietowanych, czyli dobra reklama jako taka, która „nie denerwuje i nie przeszkadza”. To także może pokazywać, że ogólnie reklama jest uznawana za zbędną, ale może być dobra, jeśli jest nienachalna, nienatarczywa i nie drażni. W tym miejscu można zastanawiać się, czy cechy te bardziej określają sam charakter reklamy, czy też może chodzi o częstotliwość jej pojawiania się w mediach.

Ostatnią kategorią, która uzyskała dość spory procent wskazań (9,7\%) w tym pytaniu, jest „śmieszna/zabawna”. Oznacza to, że ludzie oczekują od reklamy pewnej dawki humoru. Zazwyczaj kojarzy się on z pozytywnymi sytuacjami, przy których ludzie dobrze się bawią i relaksują. Może więc dlatego humor w reklamie sprawia, że równocześnie jest ona pozytywnie konotowana przez odbiorców. Można podejrzewać, że zabawność reklamy jest również utożsamiana przez respondentów z jej lepszym zapamiętaniem i tym, że może skłaniać odbiorców to przekazywania jej treści dalej, np. w formie opowiadania komuś, co się ostatnio widziało śmiesznego. 
Zaskakujące jest, że w odpowiedziach na to pytanie rzadko pojawiały się cechy wskazujące stricte na jakość czy wykonanie reklamy. Przypuszczano, że większy nacisk położony będzie chociażby na profesjonalizm realizacji czy sposób wykonania. W obu przypadkach były to jednak jednostkowe odpowiedzi. Można zatem odnieść wrażenie, że dobra reklama w opinii respondentów to przede wszystkim pomysł i zawartość, która jest kluczem do tego, czy reklamę można uznać za dobrą. Mniej ważna jest realizacja.

Tabela 2. Jaka jest Pana/Pani zdaniem zła reklama? Wyniki ogólne

\begin{tabular}{|c|c|c|c|}
\hline \multirow{2}{*}{ Kategoria } & \multirow{2}{*}{ Najczęstsze odpowiedzi } & \multicolumn{2}{|c|}{ Ogółem } \\
\hline & & Liczba & $\%$ \\
\hline schematyczna/nudna & $\begin{array}{l}\text { nudna }-24 \text {; schematyczna }-5 \text {; nieciekawa }-3 \text {; } \\
\text { powtarzalna }-3 \text {; dosłowna }-2\end{array}$ & 58 & 22,4 \\
\hline denerwująca & $\begin{array}{l}\text { nachalna }-10 \text {; agresywna }-7 \text {; głośna }-5 \text {; } \\
\text { krzykliwa }-5 \text {; irytująca }-4\end{array}$ & 42 & 16,2 \\
\hline wulgarna/obraźliwa & $\begin{array}{l}\text { wulgarna }-10 \text {; żenująca }-4 \text {; obraźliwa }-4 \text {; } \\
\text { prymitywna }-3 \text {; stereotypowa }-3\end{array}$ & 41 & 15,8 \\
\hline długa/przegadana & długa -11 ; przegadana -5 ; monotonna -2 & 25 & 9,7 \\
\hline głupia/banalna & $\begin{array}{l}\text { głupia }-4 \text {; infantylna }-4 \text {; banalna }-3 \text {; śmieszna } \\
\text { na siłę }-3\end{array}$ & 19 & 7,3 \\
\hline brzydka/nieestetyczna & brzydka -4 ; niesmaczna -4 ; nieestetyczna -2 & 14 & 5,4 \\
\hline niedopracowana & nieprzemyślana -3 ; & 10 & 3,9 \\
\hline skupiona na sprzedaży & ukierunkowana na sprzedaż -2 & 6 & 2,3 \\
\hline konkretna reklama & Media Expert - 5 & 6 & 2,3 \\
\hline niezrozumiała & niezrozumiała -2 & 6 & 2,3 \\
\hline sztuczna & fałszywa -2 & 5 & 1,9 \\
\hline nie zapada w pamięć & nie zapada w pamięć -2 & 4 & 1,5 \\
\hline każda & każda -3 & 3 & 1,2 \\
\hline inne & pojedyncze odpowiedzi & 20 & 7,7 \\
\hline & Razem & 259 & 100,0 \\
\hline
\end{tabular}

Źródło: opracowanie własne.

W drugiej części ankiety, dotyczącej skojarzeń ze złą reklamą, również nie pojawiła się kategoria, która w znaczący sposób dominowałaby ilościowo nad pozostałymi. W tym przypadku najliczniej reprezentowana kategoria to „schematyczna/nudna”, 
która uzyskała 22,4\% wskazań. Zdecydowanie najczęstsza odpowiedź, która została do niej zaklasyfikowana, to „nudna”.

Innymi znaczącymi ilościowo kategoriami w tym pytaniu są „denerwująca” oraz „wulgarna/obraźliwa”. Uzyskały one praktycznie identyczne wyniki. Kategoria „denerwująca” otrzymała zdecydowanie więcej wskazań niż opozycyjna kategoria „nie denerwuje/nie przeszkadza” w pytaniu dotyczącym dobrej reklamy. Wskazuje to, że kwestia irytacji reklamą ma większe znaczenie dopiero wtedy, gdy się pojawia, i mniej cenimy sobie brak irytacji reklamą, kiedy jej nie doświadczamy. Irytacja w takim ujęciu ma znaczenie pejoratywne, $\mathrm{w}$ przeciwieństwie do rozumienia terminu „irytacja” w konstruktywizmie. Tam bowiem jest to funkcja neutralna, a nawet pozytywna, która odpowiada za zagospodarowanie uwagi odbiorcy i umożliwia wytworzenie nowych ofert komunikacyjnych.

Kategoria „wulgarna/obraźliwa” nie ma ilościowego odpowiednika po stronie postrzegania dobrej reklamy, w związku z czym możemy przyjąć, że brak wulgarności jest swego rodzaju normą i wydaje się naturalny, natomiast pojawienie się elementów obraźliwych i wulgarnych znacząco wpływa na klasyfikację reklamy jako złą. Kolejną kategorią jest „długa/przegadana” (9,7\%), która jest zbliżona ilościowo do kategorii „łatwa/prosta”. Czas i zawartość treściowa wydają się więc kryteriami, które w podobny sposób wpływają na definiowanie dobrej i złej reklamy.

Warto zwrócić uwagę na to, że w pytaniu o cechy złej reklamy pojawia się kryterium jej estetyki. Kategoria „brzydka/nieestetyczna” nie jest co prawda zbyt liczna $(5,4 \%)$, ale pokazuje, że odbiorcom łatwiej w odniesieniu do reklamy powiedzieć, że jest brzydka, niż że jest ładna.

W odpowiedziach dotyczących cech złej reklamy respondenci praktycznie w ogóle nie zwracali uwagi na to, że jest ona „niekreatywna” lub „nieśmieszna”. Biorąc pod uwagę, że w odniesieniu do dobrej reklamy były to ważne czynniki, można odnieść wrażenie, że kreatywność i humor są w reklamie cechami pozytywnymi, natomiast gdy ich brakuje, niekoniecznie musi to oznaczać, że reklama jest zła.

\section{Elementy rozpoznawcze dobrej i złej reklamy}

Zadając pytanie „Po czym poznaje się Pana/Pani zdaniem dobrą/złą reklamę?”, szukano odpowiedzi wyjaśniającej, co powoduje, że reklama klasyfikowana jest jako dobra lub jako zła. Może się wydawać, że jest ono zbliżone znaczeniowo do wcześniejszych pytań, jednak analiza odpowiedzi pokazuje, że te kwestie są oddzielane. W pytaniu „Jaka jest dobra/zła reklama?" chodzi raczej o wyobrażenia odbiorców na temat definiowania reklamy. Natomiast pytanie o to, po czym poznaje się dobrą/złą reklamę, odnosi się do sfery realnej i zastanej, czyli możliwości jej klasyfikacji, gdy już ją widzimy. 
Tabela 3. Po czym poznaje się Pana/Pani zdaniem dobra reklamę? Wyniki ogólne

\begin{tabular}{|c|c|c|c|}
\hline \multirow{2}{*}{ Kategoria } & \multirow{2}{*}{ Najczęstsze odpowiedzi } & \multicolumn{2}{|c|}{ Ogółem } \\
\hline & & Liczba & $\%$ \\
\hline po (dobrej) jakości wykonania & $\begin{array}{l}\text { grafika }-5 \text {; estetyka }-4 \text {; kolorystyka } \\
-3\end{array}$ & 40 & 19,0 \\
\hline trafia do odbiorców & $\begin{array}{l}\text { skuteczność }-4 \text {; dopasowanie do } \\
\text { odbiorcy }-3 \text {; reakcja }-3\end{array}$ & 29 & 13,8 \\
\hline po oryginalności & $\begin{array}{l}\text { oryginalna }-5 \text {; kreatywna }-4 \text {; } \\
\text { pomysł }-3\end{array}$ & 25 & 11,9 \\
\hline jest zapamiętana & $\begin{array}{l}\text { zapada w pamięć }-8 \text {; jest zapamiętana } \\
-4 \text {; zwraca uwagę }-3\end{array}$ & 24 & 11,4 \\
\hline jest dyskretna & $\begin{array}{l}\text { nienachalna }-3 \text {; nie przeszkadza }-3 \text {; } \\
\text { prosta }-2\end{array}$ & 18 & 8,6 \\
\hline ciekawi & ciekawa -6 ; przyciąga uwagę -3 & 17 & 8,1 \\
\hline skłania do zakupu & zachęca do kupna -3 ; działa -2 & 15 & 7,1 \\
\hline jest w niej humor & po humorze -4 ; śmieszna -2 & 9 & 4,3 \\
\hline atrakcyjna treść & pojedyncze odpowiedzi & 9 & 4,3 \\
\hline jest aktualna & pojedyncze odpowiedzi & 4 & 1,9 \\
\hline jest zwięzła & pojedyncze odpowiedzi & 4 & 1,9 \\
\hline inne & pojedyncze odpowiedzi & 16 & 7,6 \\
\hline & Razem & 210 & 100,0 \\
\hline
\end{tabular}

Źródło: opracowanie własne.

Najczęściej wymieniana kategoria dotyczyła szeroko pojętej jakości wykonania reklamy. 19\% badanych stwierdziło, że dobrą reklamę można poznać po tym, że „jest dobrze wykonana”. Do tej kategorii zaliczało się bardzo wiele, często pojedynczych odpowiedzi, co wskazuje, że jakość wykonania ma w tym wypadku niezwykle bogatą semantykę. Najczęstsze odpowiedzi w tej kategorii to estetyka, grafika i kolorystyka, ale razem mają one jedynie 12 na 40 wskazań. Do tej kategorii zaklasyfikowano całą gamę odpowiedzi odnoszących się do jakości reklamy, począwszy od gry aktorskiej, przez dobór muzyki, aż po dobre hasła (claimy). Bardzo ciekawe jest to, że jakość wykonania była sporadycznie wymieniana w odpowiedziach na pytanie „Jaka jest dobra reklama?". Wskazuje to, że odbiorcy dopiero, gdy mają kontakt z reklamą, zwracają uwagę na jej szeroko rozumianą jakość (estetykę), natomiast w sferze wyobrażeń $\mathrm{z}$ nią związanych ta kwestia nie jest komunikowana. 
Zdecydowanie mniejsze znaczenie w tym pytaniu ma dla respondentów „zaciekawienie i oryginalność" jako elementy ważne przy rozpoznaniu dobrej reklamy. O ile wcześniej były to dominujące kategorie, o tyle teraz razem mają 20\% wskazań. Podobną zależność można zauważyć, jeśli chodzi o kategorię „humoru”. Jedynie 4,3\% respondentów odpowiedziało, że to właśnie po humorze czy śmiechu można poznać dobrą reklamę.

Tym razem liczniej reprezentowane są kategorie rynkowe, tzn. kładące nacisk na to, by dobra reklama była skuteczna, trafiła do odbiorców $(13,8 \%)$ czy skłaniała do zakupu reklamowanego produktu $(7,1 \%)$. Widać tu wyraźne nawiązanie do przedstawianej wcześniej, mocno obecnej w paradygmacie ekonomicznym, sprzedażowej funkcji reklamy. Może to wynikać z tego, że spora część odbiorców reklamy traktuje skuteczność na równi ze wzrostem sprzedaży i uznaje, iż jest to miernik dobrej reklamy. Uważają oni, że łatwo można skorelować daną kampanię ze wzrostem sprzedaży i jest to oczywista współzależność.

Tabela 4. Po czym poznaje się Pana/Pani zdaniem złą reklamę? Wyniki ogólne

\begin{tabular}{|c|c|c|c|}
\hline \multirow{2}{*}{ Kategoria } & \multirow{2}{*}{ Najczęstsze odpowiedzi } & \multicolumn{2}{|c|}{ Ogółem } \\
\hline & & Liczba & $\%$ \\
\hline po (złej) jakości wykonania & $\begin{array}{l}\text { niska jakość }-4 \text {; jest brzydka }-3 \text {; } \\
\text { chaotyczność }-2\end{array}$ & 44 & 23,5 \\
\hline jest nudna & nudna -7 ; długość -4 ; schematyczność -3 & 33 & 17,6 \\
\hline jest wulgarna & obraźliwa -4 ; chamstwo -2 ; wulgarna -2 & 32 & 17,1 \\
\hline przeszkadza/denerwuje & $\begin{array}{l}\text { denerwująca }-5 \text {; krzykliwa }-4 \text {; głośna }-3 \text {; } \\
\text { nachalna }-3\end{array}$ & 25 & 13,4 \\
\hline $\begin{array}{l}\text { nie przyciąga uwagi/ } \\
\text { niezapamiętana }\end{array}$ & $\begin{array}{l}\text { po reakcji odbiorcy }-3 \text {; niezapamiętana }-2 \text {; } \\
\text { niezauważona }-2\end{array}$ & 21 & 11,2 \\
\hline nieatrakcyjna treść & pojedyncze odpowiedzi & 7 & 3,7 \\
\hline niedopracowana & pojedyncze odpowiedzi & 3 & 1,6 \\
\hline jest nieskuteczna/nie działa & po nieskuteczności -2 & 6 & 3,2 \\
\hline pokazuje produkt & pokazuje produkt -2 & 5 & 2,7 \\
\hline inne & pojedyncze odpowiedzi & 11 & 5,9 \\
\hline & Razem & 187 & 100,0 \\
\hline
\end{tabular}

Źródło: opracowanie własne.

W drugiej części pytania, tym razem odnoszącego się do złej reklamy, widać, że najliczniejsza kategoria jest tożsama z najliczniejszą kategorią z pierwszej części pytania. Jeśli w przypadku pytania o to, po czym poznaje się dobrą reklamę, największa 
liczba respondentów odpowiedziała, że „po jakości jej wykonania” (w zamyśle dobrej), to w wypadku determinantów możliwości poznania złej reklamy jest to „zła jakość wykonania”. W tej kategorii odpowiedzi także były bardzo rozdrobnione. Te najczęściej wymieniane (niska jakość, brzydka) odnosiły się raczej do reklamy jako całości niż do jej poszczególnych komponentów, jak np. grafika, kolorystyka. Można więc zauważyć, że jakość, niezależnie od tego, czy jest dobra, czy zła, stanowi czynnik, za pomocą którego reklama jest często (lub jak w przypadku tego badania - najczęściej) klasyfikowana w kategorii „dobra/zła”.

Pozostałe kategorie, które uzyskały ponad $10 \%$ odpowiedzi, pokrywają się z najliczniejszymi kategoriami z pytania „Jaka jest zła reklama?”. Wyróżnia się jedynie kategoria „nie przyciąga uwagi/niezapamiętana”, która zdecydowanie częściej była wymieniana w pytaniu „Po czym poznaje się złą reklamę?” (11,2\%) niż „Jaka jest zła reklama?” (2,9\%).

\section{Osoby tworzące dobre i złe reklamy}

Kolejne pytanie w odróżnieniu od wcześniejszych nie odnosi się do samych reklam, ale ich twórców. Respondenci proszeni byli o odpowiedź na pytanie „Jakie są osoby, które robią dobre/złe reklamy?”. Domyślano się, że będą na nie odpowiadali dość chętnie, ponieważ podobnie jak w przypadku samej reklamy, tak w wypadku osób, które są odpowiedzialne za jej powstawanie, respondenci potrafią skonstruować odpowiedni ich obraz. Pytanie to miało na celu sprawdzenie, czy cechy dotyczące samej reklamy przekładają się odpowiednio na cechy jej twórców.

Tabela 5. Jakie są osoby, które robią dobre reklamy? Wyniki ogólne

\begin{tabular}{|c|c|c|c|}
\hline \multirow{2}{*}{ Kategoria } & \multirow{2}{*}{ Najczęstsze odpowiedzi } & \multicolumn{2}{|c|}{ Ogółem } \\
\hline & & Liczba & $\%$ \\
\hline kreatywne & kreatywne -55 ; pomysłowe -18 ; twórcze -8 & 93 & 39,6 \\
\hline otwarte & otwarte -12 ; ciekawe świata -4 ; świadome -3 & 30 & 12,8 \\
\hline inteligentne & inteligentne -17 ; myślące -3 ; błyskotliwe -2 & 30 & 12,8 \\
\hline wykształcone & wykształcone -6 ; oczytane -4 ; kompetentne -3 & 23 & 9,8 \\
\hline ambitne & ambitne -4 ; energiczne -2 & 13 & 5,5 \\
\hline dowcipne & zabawne -5 ; dowcipne -3 ; towarzyskie -3 & 13 & 5,5 \\
\hline empatyczne & empatyczne -4 & 8 & 3,4 \\
\hline młode/nowoczesne & młode -2 & 3 & 1,3 \\
\hline bogate & bogate -2 & 3 & 1,3 \\
\hline inne & pojedyncze odpowiedzi & 19 & 8,1 \\
\hline & Razem & 235 & 100,0 \\
\hline
\end{tabular}

Źródło: opracowanie własne. 
W pierwszej części tego pytania, odnoszącej się do dobrej reklamy, po raz pierwszy w skali całego badania udało się wyodrębnić kategorię, która ilościowo wyraźnie dominuje nad pozostałymi. Respondenci bardzo chętnie określali osoby, które robią dobre reklamy, jako „kreatywne” (ewentualnie „pomysłowe”, „twórcze”). Kategoria ta uzyskała prawie $40 \%$ wszystkich odpowiedzi. W porównaniu z najliczniejszymi kategoriami z poprzednich pytań, które nie przekraczały $25 \%$, tę można uznać za naprawdę liczną i semantycznie dominującą kategorię. Kreatywność to cecha, która zdaniem respondentów jest więc niezbędna do robienia dobrych reklam.

Poza kreatywnością innymi licznymi kategoriami, jakimi respondenci określają osoby robiące dobre reklamy, są „otwartość” i „inteligencja”. Obie uzyskały po 12,8\% odpowiedzi. Otwartość to kategoria typowo personalna i nie ma swojego odpowiednika w adekwatnym pytaniu o dobrą reklamę. Natomiast inteligencja osób robiących dobre reklamy w pierwszym pytaniu nie była oddzielną kategorią, tylko współtworzyła jedną szerszą — razem z kreatywnością. W tym wypadku zrezygnowano jednak z takiego połączenia, ponieważ stwierdzono, że odpowiedzi dotyczące kreatywności i inteligencji osób są bardziej rozdzielne niż w przypadku samej reklamy.

Tabela 6. Jakie są osoby, które robią złe reklamy? Wyniki ogólne

\begin{tabular}{|c|c|c|c|}
\hline \multirow{2}{*}{ Kategoria } & \multirow{2}{*}{ Najczęstsze odpowiedzi } & \multicolumn{2}{|c|}{ Ogółem } \\
\hline & & Liczba & $\%$ \\
\hline niekreatywne & $\begin{array}{l}\text { schematyczne }-13 \text {; mało kreatywne }-4 \text {; } \\
\text { zamknięte }-4\end{array}$ & 43 & 25,3 \\
\hline leniwe/cwane & leniwe -12 ; cwane -4 ; ignoranci -3 & 25 & 14,7 \\
\hline egoistyczne & egoistyczne -3 & 11 & 6,5 \\
\hline niedoświadczone & $\begin{array}{l}\text { niewykształcone }-3 \text {; niedoświadczone }-2 \text {; } \\
\text { niekompetentne }-2\end{array}$ & 14 & 8,2 \\
\hline głupie & głupie -7 & 11 & 6,5 \\
\hline nudne & ograniczone -3 ; nudne -9 & 12 & 7,1 \\
\hline bez gustu & bez gustu -3 & 6 & 3,5 \\
\hline nastawione na zysk & ukierunkowane na zysk -5 & 8 & 4,7 \\
\hline nieprzygotowane & mówią, a nie komunikują -2 & 4 & 2,4 \\
\hline bez skrupułów & pojedyncze odpowiedzi & 3 & 1,8 \\
\hline kreatywne & pojedyncze odpowiedzi & 3 & 1,8 \\
\hline zawzięte & pojedyncze odpowiedzi & 3 & 1,8 \\
\hline modne & hipsterzy -2 & 3 & 1,8 \\
\hline
\end{tabular}




\begin{tabular}{|l|l|c|c|}
\hline \multirow{2}{*}{ Kategoria } & \multicolumn{1}{|c|}{ Najczęstsze odpowiedzi } & \multicolumn{2}{c|}{ Ogółem } \\
\cline { 3 - 4 } & & Liczba & $\%$ \\
\hline chamskie & pojedyncze odpowiedzi & 2 & 1,2 \\
\hline stare & stare -2 & 2 & 1,2 \\
\hline inne & pojedyncze odpowiedzi & 15 & 8,8 \\
\hline \multicolumn{2}{|l|}{ Razem } & 170 & 100,0 \\
\hline
\end{tabular}

Źródło: opracowanie własne.

Skoro w pierwszej części pytania, dotyczącej osób, które robią dobre reklamy, kreatywność była mocno dominującą kategorią, to można się było spodziewać, że w przypadku opozycji, czyli pytania o osoby, które robią złe reklamy, licznie reprezentowana będzie przeciwna kategoria, czyli odpowiedzi, że są one niekreatywne. Widać jednak, że w przypadku twórców złej reklamy brak kreatywności $(25,3 \%)$ nie jest tak dominujący jak kreatywność w wypadku autorów dobrej reklamy $(39,6 \%)$.

Respondenci oprócz wymienionej już kategorii „niekreatywne” wskazali, że spore znaczenie ma kategoria „leniwe/cwane”-14,7\%.

\section{Wnioski}

Głównym wnioskiem, jaki płynie $\mathrm{z}$ analizy badania konstruowania obrazu dobrej i złej reklamy, jest to, że odbiorcy nie mają większych problemów z oceną i charakterystyką reklamy na osi „dobra-zła”. Widać, że dość wyraźnie i swobodnie dokonują tego rozróżnienia. Jedynie w pojedynczych przypadkach zdarzało się, że któraś kategoria czy cecha były wymienianie po obu stronach. Wskazuje to, że na ogólnym poziomie semantycznym dobra i zła reklama są pojęciami odległymi od siebie. Jednak wchodząc w operacjonalizację zjawiska dobrej i złej reklamy, można założyć, że każda z osobna nie jest już tak jednorodna semantycznie. Praktycznie w żadnym pytaniu nie wyodrębniono kategorii, która wyraźnie dominowałaby nad pozostałymi. Wyjątkiem jest tutaj stwierdzenie, że osoby, które robią dobre reklamy, są kreatywne (prawie $40 \%$ odpowiedzi respondentów). W pozostałych przypadkach można zaobserwować kilka kategorii, które miały podobny wynik procentowy. Oznacza to, że przyporządkowanie reklamy do kategorii „dobra-zła” jest procesem dość subiektywnym i nie da się jednoznacznie stwierdzić, jaka ma być reklama, aby była uważana za dobrą/złą. Oczywiście patrząc na wyniki analizy, można połączyć wszystkie wymienione cechy (a przynajmniej te najczęstsze), aby uzyskać „stan idealny”.

We wszystkich badaniach na temat nastawienia do reklamy wyniki pokazują, że ludzie nie ufają reklamie, uważają, że jest jej za dużo, a jej poziom jest słaby. Nie 
zmienia to jednak faktu, że jesteśmy skazani na kontakt z reklamą, gdyż stanowi ona immanentną część świata medialnego, w którym funkcjonujemy. Zdecydowanej większości reklam, które nas otaczają, nawet nie jesteśmy w stanie zauważyć i przetworzyć, gdyż jest ich tak dużo, że percepcyjnie jest to po prostu niemożliwe. Niejasne także jest, co jest reklamą, a co nią nie jest. W związku z tym jedynie w sferze domysłów pozostaje, co można mieć na myśli, tworząc konstrukty reklamy na osi „dobra-zła”. Ważne jednak, że udało się wyodrębnić relewantne dla obu konstruktów wartości, które mogą być traktowane jako odpowiedź na pewne zapotrzebowanie komunikacyjne na produkowanie i perpetuowanie adekwatnych ofert komunikacyjnych dla określonej publiczności.

\section{Qualities affecting the perception and opinion about advertising}

Summary

When we ask people "What is this advertisement?" or "What is your opinion about this advertisement?" their judges will be probable very simple. They said, that advertisement is good or bad, nice or ugly etc. We can see there are very general judges, which are difficult to interpret scientifically.

In this article is presented the exemplary solution of this problem by checking how people understand the phenomenon of good and bad advertisement and what qualities are associated with them. On the one hand, there are many general terms, but if we try to check them through the research of communication it turns out that good and bad advertisements are constructs which have different images.

Both constructs (good and bad) of advertising are clearly different. It means that respondents didn't create one, dominant image of good and bad advertisement. Although opinions of respondents are different it seems we can find and select areas which dominate in both constructs. In the case of the topic of a good advertisement that area is certainly creativity. In any questions related to a good advertisement it plays an important role. Therefore, it seems that the creativity is a key element in the construction of a good advertisement. On the other hand, if there is a bad advertisement, it is observed that main areas are boredom (opposition to the creativity), and furthermore vulgarity and causing nervousness. 